\title{
Biopsy of Palate
}

National Cancer Institute

\section{Source}

National Cancer Institute. Biopsy of Palate. NCI Thesaurus. Code C51639.

Removal of tissue from the palate for microscopic examination. 